\title{
Visualizing the Gothic in Neil Gaiman's The Graveyard Book and Its Illustrated Adaptations
}

\begin{abstract}
This article argues that Neil Gaiman's appropriation of the Gothic topos in The Graveyard Book (2008) deliberately unsettles its genre. No stranger to the interaction of word and image on the page, Gaiman's fascination with the visual can be seen on the first page of his novel, a page that communicates in word and image. Interestingly, P. Craig Russell's graphic novel version (2014) develops the hybridity of Gaiman's source text in more depth. Not only are these volumes a further testament to the visual potential of Gaiman's Graveyard Book; they also visually mirror Gaiman's approach to the Gothic: it unsettles and transforms the once-frightening world of ghosts and goblins into a world in which the child-protagonist and reader would feel at home.
\end{abstract}

Keywords: adaptation, Chris Riddell, Dave McKean, Gothic, graphic novel, The Graveyard Book, illustrated novels, interpretation, Little Nemo, Neil Gaiman, P. Craig Russell, unheimlich, vampires, villains, Yellow Kid

\section{Introduction}

Neil Gaiman is certainly no stranger to the Gothic - Gothic motifs and images in the form of old houses with secret spaces, ghosts, doppelgängers, dream-visions, and dark tunnels crop up in his Sandman series (1989-), Coraline (2002), The Wolves in the Walls (2003), and, most recently, The Graveyard Book (2008). Fascinatingly, the "threats associated with supernatural and natural forces, imaginative excesses and delusions, religious and human evil, social transgression, mental disintegration and spiritual corruption" (Botting 1996, 2), key thematic concerns of the literary Gothic, are not Gaiman's principal concern in his children's fiction. While Gaiman brings Gothic resonances to a range of age-groups in children's literature through this imagery, the more serious preoccupations of the literary Gothic, such as dark secrets and shameful mysteries, a focus on monstrosity and madness, desecration and blasphemy, self-alienation, trauma, and paranoia (McGillis 2008, 227), are generally played down in favour of the more explicitly visual trappings of the Gothic. More generally, Gaiman's focus in many of his children's texts is on the Gothic atmosphere and the delicious visual and 
narrative opportunities it offers his young protagonists. Gaiman employs iconic Gothic visuals to create a moody, even haunted, atmosphere and setting in which to allow his protagonists to explore the intricate passages of their own identities.

His introduction of the enormous cemetery in The Graveyard Book, for example, invokes stock Gothic components (fog, moonlight, a funeral chapel, tombs and vaults, etc.) in a gentle way, while drawing a young reader into Bod's (the protagonist's) physical and metaphorical adventure through the use of the second-person pronoun:

The fog was thinner as you approached the top of the hill.

The half-moon shone, not as bright as day, not by any means, but enough to see the graveyard, enough for that.

Look.

You could see the abandoned funeral chapel, iron doors padlocked, ivy on the sides of the spire, a small tree growing out of the guttering at roof level.

You could see stones and tombs and vaults and memorial plaques. You could see the occasional dash or scuttle of a rabbit or a vole or a weasel as it slipped out of the undergrowth and across the path.

You would have seen these things, in the moonlight, if you had been there that night.

You might not have seen a pale, plump woman, who walked the path near the front gates, and if you had seen her, with a second, more careful glance you would have realized that she was only moonlight, mist, and shadow. (Gaiman 2008a, 12)

Gaiman transforms the Gothic, making use of the thrills and chills that popular Gothic provokes in readers in order to pursue his interest in the developmental and psychological growth of the child. This is not to say that Gaiman's Gothic settings do not provoke a sense of threat in the characters (and readers). On the contrary, the sprawling house in which Coraline faces her predatory other-mother, for example, is a perfect example of the unheimlich of the Gothic, a terrifyingly pleasant prison in which Coraline must outsmart her own anxieties and insecurities. Thus, in Gaiman's novels, house and graveyard become settings and even larger metaphors for the protagonists' attempts to develop agency over their own psyches and everyday lives. Gaiman redeploys the Gothic, appealing to a young reader's predilection for hauntings and horrors, while focusing on the complicated psyche of the child. This transformation of the Gothic supports Fred Botting's claim that, in the twentieth and twenty-first centuries, the Gothic has become difficult to define because its forms and figures have become so diffuse (1996, 14).

In the latter half of the twentieth century, Gothic tales began to achieve prominence in children's literature, preying on the instinctive fears and desires of young readers. For Michael Howarth, twentieth-century Gothic children's stories allow readers to lose themselves in the anguish of another character, supplying "the 
emotional training wheels we all need to mature" $(2014,8)$. Karen Coats sees the children's Gothic, typified by Gaiman's Coraline, as helping children cope with the "underlying trauma" they face $(2008,77)$. Chloe Buckley argues that research analysing Gaiman's “psychic Gothic” originates from and feeds back into a late twentieth-century trend of rereading Golden Age fiction as both Freudian uncanny and Gothic, a process that blurs these terms $(2015,58)$. Past research has sought to champion children's Gothic literature in predominantly psychoanalytical terms, neglecting other aspects of Gaiman's oeuvre, in this case, the visual adaptations of Gaiman's Gothic.

Surprisingly little critical work has been done on Neil Gaiman's use of Gothic tropes in his illustrated novels. The Graveyard Book deliberately employs motifs from popular horror and literary Gothic, motifs that in turn become a significant part of the visual appeal of the novel's two illustrated editions (Gaiman 2008a, illus. McKean; Gaiman 2008b, illus. Riddell) and its two-volume graphic novel adaptation (Gaiman 2014) spearheaded by P. Craig Russell. ${ }^{1}$ As Coats asserts: "Ethically speaking, Gaiman does Gothic old-school, that is, the demarcations between good and evil are clear, and even when the evil is within, it is soundly defeated and expelled by a problem-solving hero or heroine" $(2008,78)$. Although the Gothic terror of The Graveyard Book - provoked through the archetypal murder of a family and the predatory search for the innocent child - forms the narrative, visual backdrop, and setting of the story, Gaiman's novel is actually more concerned with the basic values of kindness, humanity, and love than with the lurid and taboo so typical of the Gothic mode. In this way, Gaiman transforms Gothic conventions to allow his principal protagonist, Nobody (Bod) Owens, to take refuge in the strangeness of the Gothic world as he grows into adolescence. Protagonist and young reader enjoy a temporary sense of belonging in The Graveyard Book, one that proves that the Gothic as a genre can help rather than "shatter and discompose the [child's] Spirits" (Townshend 2008, 18), as John Locke once claimed in Some Thoughts Concerning Education (1693). Although Gaiman tackles violent topics (murder, abandonment, betrayal), forcing the reader to address some harsh realities of life, the Gothic setting and atmosphere comfort rather than shatter a young reader. In turn, Gaiman's unsettling of the Gothic provides creative possibilities for the visual artists who adapt his text. Not only are the two illustrated editions and graphic novel a testament to the visual potential of Gaiman's Graveyard Book; they mirror Gaiman's own approach to the Gothic, unsettling the

1 My recent article Halsall (2017) compares the ten distinct visual approaches to Gaiman's novel that exist in the two-volume graphic novel adaptation (compiled by P. Craig Russell), as well as in Chris Riddell's British children's edition and Dave McKean's American edition. 
once-frightening world of ghosts and goblins, and transforming it into a world in which the young protagonist and reader can feel at home. That three different adaptations of the same text can be new yet familiar at the same time also speaks to the adaptability of the Gothic in general and the ways these specific illustrated texts remain recognizably Gothic even when adapted to different contexts.

\section{Adaptation as interpretation}

In Romanticism and the Gothic (2000), Michael Gamer refers to the Gothic as a shifting aesthetic with an essential ability to move between and among literary and cultural forms and even media. In describing the Gothic as "culturally amphibious," Angela Wright captures this ability of the Gothic to thrive in contemporary fiction, drama, poetry, and film because of its ability to move and transform $(2007,5)$. These claims continue to hold true in the twenty-first century, specifically, in literature for children. Coraline, Monster High, and the Series of Unfortunate Events, Spiderwick Chronicles, and Twilight saga series, are literary, visual, and filmic texts that prove that young readers and viewers retain an affinity for the Gothic, for ghosts and goblins, hauntings and horrors. Fear has become a powerful marketing tool for the promotion and sale of books and commodities, not to mention films and video games for young readers and viewers. Scholars have begun to analyse these Gothic tendencies in children's literature, though this work remains on the periphery of Gothic criticism in general. Anna Jackson, Karen Coats, and Roderick McGillis suggest that a reader enjoys experiencing the pleasure of a shiver or a shake, confident that (s)he does not live in the strange Gothic world the children's novel evokes $(2008,11)$. The critic Michael Howarth accounts for the distinctly psychological purposes that Gothic children's texts serve. For Howarth, the Gothic genre allows young readers to process conflicting feelings about themselves and the world around them (2014, 2). For many young readers and viewers, the appeal of the Gothic is the appeal of danger: its literary, visual, or filmic world gives youngsters a space that is safe from fear, in which they can safely indulge their curiosity about evil and death.

As the critic Linda Hutcheon reminds her readers, thanks to the complexities of new media and the new platforms on which stories are now available, adaptation is always a collective process, moving from a "solo model of creation to a collaborative one" $(2013,80)$. This collaborative approach is certainly evident in the publication formats of The Graveyard Book, which match the heimlich and unheimlich of the Gothic with the familiarity and novelty of adaptation. A number of illustrated editions of Gaiman's 2008 novel already exist, each of 
which makes much of the text's Gothic elements while producing something quite distinct. Dave McKean and Chris Riddell, respectively, produced illustrations for the American and British editions of the novel. P. Craig Russell's graphic novel adaptation of Gaiman's The Graveyard Book is even more unique in terms of the collaborative nature of the project. Each of its eight chapters is adapted visually by a different artist (or team of visual artists), and the heterogeneity of form is mirrored in the heterogeneous visuals themselves, which riff off each other (and the illustrations in McKean's and Riddell's earlier illustrated editions), while providing distinctive interpretations of Gaiman's novel. This graphic novel adaptation in particular refutes Maria Nikolajeva and Carole Scott's claim that "multiple ownership and multiple intentionality lead to ambiguity and uncertainty in the validity of the interpretation" $(2001,29)$. In fact, these ten distinct visual adaptations of The Graveyard Book showcase both the collaborative partnership among all of the adapters and storytelling that quite literally occurs on several platforms without compromising the thrust of Gaiman's source text. All of these adaptations embody the two central principles of adaptation that Linda Hutcheon outlines "familiarity and novelty" $(2013,114)$ - that in turn signal the distinctive elements that they bring to Gaiman's evocation and transformation of Gothic tropes. These adaptations speak to the visual potential that Gaiman's source text offers and to the fine line the visual artists walk between producing something particular while remaining consistent with one another. Indeed, the novel's particular atmosphere and setting provide fertile ground for interpretation and point to the adaptability of the Gothic mode in general. In turn, these visual adaptations of Gaiman's Gothic story repurpose the novel to broaden its audience base and bring new readers to the literary and visual narrative(s).

For the illustrators Dave McKean and Chris Riddell, as well as the eight graphic artists featured in the graphic novel adaptation, adaptors are first interpreters and then creators. The talents of these illustrators inevitably shape the adapted text. The British illustrator Chris Riddell illustrated the UK children's edition of The Graveyard Book in 2008, and his illustrations undoubtedly helped the edition make the Kate Greenaway Medal shortlist, the first time in the award's thirty-year history that one book made both the author and illustrator shortlists. Riddell's Gothic aesthetic dovetails nicely with Gaiman's Gothic themes. Beautifully detailed line drawings preface each chapter, visually announcing the fantastical creatures that protagonist Nobody Owens will next encounter. These pen-and-ink illustrations deepen the novel's Gothic atmosphere, emphasizing shadows and darkness, not to mention featuring awkward, bony bodies and the strange, Gothic creatures that Bod encounters throughout his youth. Delighting in the visual possibilities offered by Bod's descent into Ghulheim through the Ghoulgate, for example, Riddell makes much of the odd ghouls, "lean and leathery, all 


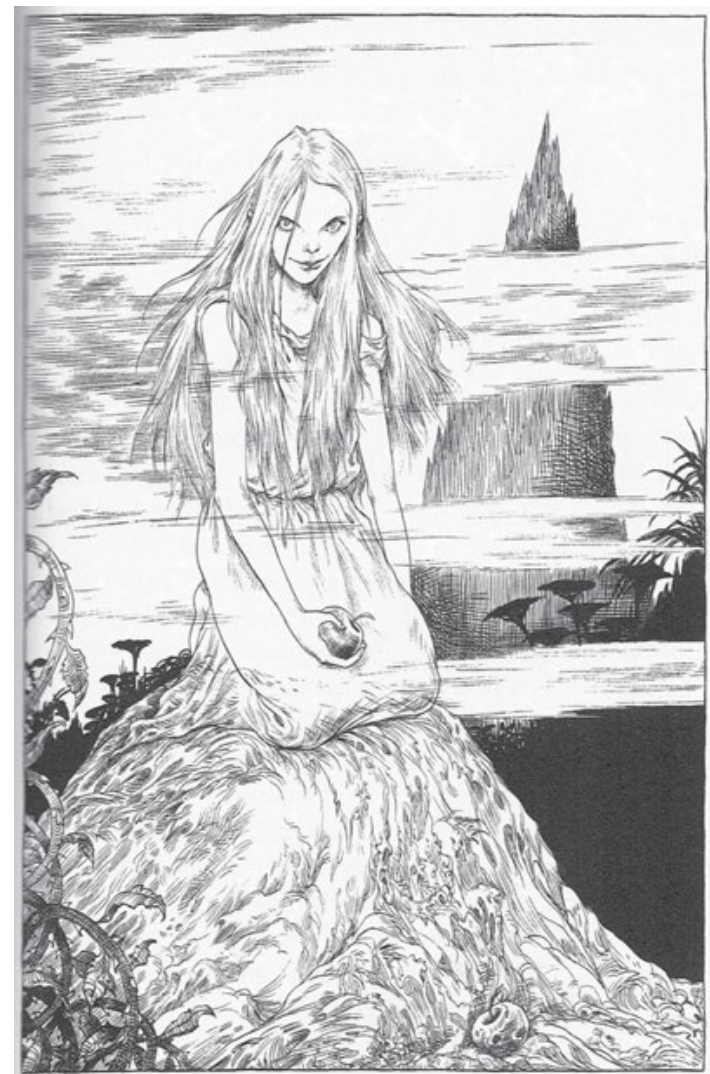

'They say a witch is buried here.'
Fig. 1: Neil Gaiman, The Graveyard Book, illustrated by Chris Riddell (New York: Harper, 2008), 91. (c) Neil Gaiman.

sinews and cartilage" (Gaiman 2008b, 67), and night-gaunts (bat-like creatures) that inhabit this hellish landscape. Following Gaiman's lead, Riddell selects images that enhance the Gothic aspect of the narrative rather than the novel's Bildungsroman elements. His illustration of Liza Hempstock is a visual mixture of fairy, sprite, and witch, for example, deepening Gaiman's initial characterization of her face as having "something of the goblin" (Gaiman 2008b, 100) in it. Riddell depicts her sitting on the unconsecrated ground in which she was buried, holding an apple, a visual nod to the rotting apple that lies beneath her, which in turn references Gothic images of decomposition. Often, Riddell's illustrated characters look out at readers, meeting the readers' eyes and bringing them into the story. Liza's unabashed look captures the mixture of shyness and sass that Gaiman first introduced into her character. In turn, the subtitle under the illustration, "They say a witch is buried here" (Gaiman 2008b, 91), invites Bod and the reader to reflect on the implications of the term when faced with her image (see fig.1). 


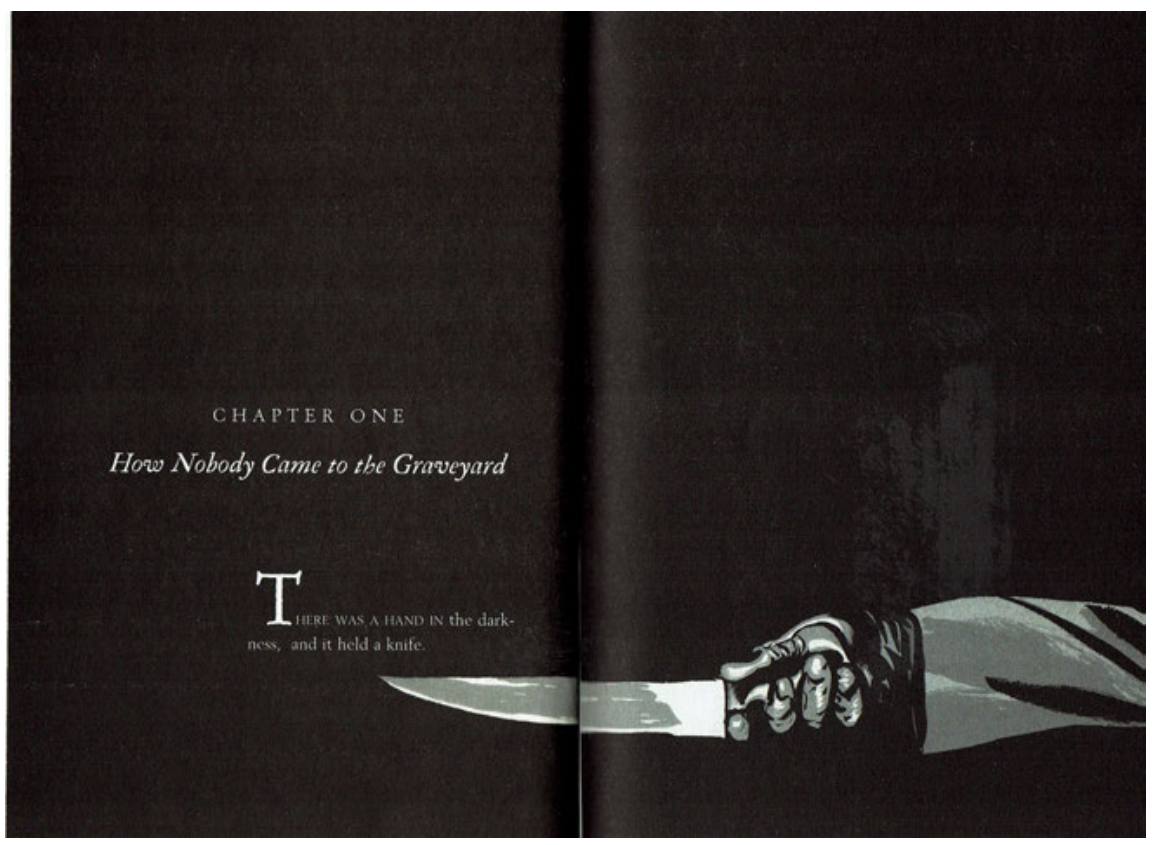

Fig. 2: Neil Gaiman, The Graveyard Book, illustrated by Dave McKean (New York: Harper, 2008), 2-3. () Neil Gaiman.

Chris Riddell's illustration of the Lady on the Grey with her "long grey dress that hung and gleamed beneath the December moon like cobwebs in the dew" (Gaiman 2008b, 149) is even more explicitly Gothic and is also reminiscent of Tim Burton's Corpse Bride with her corpse-like face, long flowing hair, and Victorian shroud. The Lady's sharp cheekbones, heavily lidded eyes, and gaunt figure visually evoke the spectre of Gothic fiction, enhancing the Gothic figures Gaiman makes much of in his narrative.

Dave McKean, with whom Gaiman has worked for many years, illustrated the UK adult edition and the American edition of The Graveyard Book. McKean's illustrations are more interactive with the text proper, often appearing above or below the typography. Presenting a very different approach in form and content to Riddell's illustrations, McKean's aesthetic enhances the source text's Gothic feel (see fig. 2).

McKean's opening page captures a reader's interest instantly through the juxtaposition of words, the dominant image of the knife, and the dark, brooding atmosphere of the page itself. On opening Gaiman's novel, a young reader falls into a world that promises to be dark and dangerous (and entirely in keeping with 
the Gothic mode), but that turns out to be safe and comforting a few pages later once our protagonist takes refuge in the graveyard of the title. McKean's aesthetic is much less realistic than that of Riddell, featuring images that are more free-flowing, with oblong angles and curves rather than precise details. Early images in the novel feature Gothic mists and an unheimlich house that becomes the scene of the terrible murder of Bod's biological family, in turn capturing the horrific potential of the domestic that is so typical of the Gothic. Like Riddell, McKean makes much of familiar Gothic visuals in his illustrated adaptation: Gothic arches shelter Bod, and the cemetery's headstones, doorways, and wrought-iron gates establish Gaiman's distinctly Gothic setting. In contrast to Riddell's precisely rendered pen-and-ink illustrations, McKean's images are more sketch-like. Through these sketches, McKean evokes the novel's Gothic traces but minimizes their horror for the reader. Likewise, in keeping with Gaiman's tendency to render the Gothic less threatening, when McKean visualizes the ghosts that inhabit the graveyard, he renders them extremely clearly, again minimizing as much as possible the fear that such spectres might evoke in a young reader. Adapted by these two masterful illustrators, Gaiman's Gothic world allows his young readers to escape from the horrors of everyday life into the mysteriously appealing graveyard on the hill, for a time at least.

Part of the pleasure of adaptation, and the adaptation of one text across a number of different platforms, comes from the "mixture of repetition and difference" that such work highlights (Hutcheon 2013, 114) and that in turn connects with the uncanny aspect of the Gothic mode itself. Expanding on the relationship between word and image that already exists in Riddell's and McKean's illustrated novel versions of The Graveyard Book, the American comic-book artist and illustrator P. Craig Russell spearheaded the project of adapting the novel as a graphic novel which was published in two volumes. Each individual chapter was adapted by a different artist or team of artists, forming a total of eight distinct visual approaches to Gaiman's source text. Volume 1 features illustrations by Scott Hampton, Tony Harris, Kevin Nowlan, P. Craig Russell, Stephen B. Scott, Galen Showman, and Jill Thompson. Volume 2 includes further work by Hampton, Nowlan, Russell, and Showman, with additional illustrations by David Lafuente. Just as The Graveyard Book is very self-conscious in drawing from different mythologies and literary genres, its graphic novel adaptation is equally self-conscious in its use of the comics medium, including stylistic allusions to EC horror comics of the 1950s, superhero comics from the 1970s and 1980s, and contemporary Japanese manga.

Although the organization of the individual pages is quite regular, the creative potential comes from the contributors, their distinctive approaches to Gaiman's Gothic story, and their abilities to balance familiarity with novelty. Like 
Riddell and McKean, these eight graphic artists mirror in visual fashion Gaiman's approach to the Gothic, which is to transform the once-frightening world of ghosts and goblins, a graveyard with all its mysterious crypts and tombs, into a world in which a young protagonist and reader would feel at home. The opening pages of volume 1 fulfil the reader's expectation of the graveyard as a Gothic space: blacksplash pages featuring gradations of shadow are overlaid by a wrought-iron fence, headstones, and a spectral Bod on the other side of the fence looking out at the reader. Kevin Nowlan's adaptation of chapter 1 begins with individual frames that feature the gore of Bod's murdered family (four out of seven frames depict pools of blood, slit throats, and blood on a knife blade, for example), introducing the horrors associated with the domestic space, typical of literary Gothic. Chapter 3, "The Hounds of God," illustrated by the graphic team of Tony Harris and Scott Hampton, enhances the threats that lurk in a graveyard and its attendant spaces. This chapter captures the resentment that six-year-old Bod feels as he is left by his godfather, Silas, with Miss Lupescu, his infrequent guardian. Bod's sulkiness is captured by the exaggerated, rather unpleasant aesthetic that the graphic team employs to depict him. Fascinatingly, a transition between Harris's and Hampton's artistic styles occurs between pages 76 and 77 of chapter 3, effecting narratively and visually a change of scenery (from graveyard to Ghulheim) and in turn an enhancement of the Gothic visuals. Visually referencing Little Nemo's fall into Slumberland, Scott Hampton illustrates Bod's descent into horrifying Ghulheim, an unpleasant secondary world whose Gothicism is enhanced by the different colour palette that Hampton employs (one that features reds, browns, and purples). In Hampton's visualization of Ghulheim as a kind of Gothic hell, faces are ugly and difficult to distinguish, typical of a dream world. The characters whom Bod meets are a hodgepodge of historical figures - the Duke of Westminster, the Bishop of Bath and Wells, the Honourable Archibald Fitzhugh, the thirty-third President of the United States, the Emperor of China, and Victor Hugo. All of these figures are aesthetically unpleasant, threatening, even monstrous. Teeth are a focus in all of Hampton's visuals; the ghouls' mouths hang open and tongues loll out to signal the fact that they appear to be appetite incarnate. As scavengers and parasites, these figures inspire the repulsion that is characteristic of the Gothic. Returning home to the graveyard, Bod appreciates even more deeply how much the cemetery has become his safehaven, his home even, and this comfort is in turn reflected in the more aesthetically pleasing visuals. 


\section{Gothic villains redeployed}

If we were to agree with Karen Coats's claim that, "ethically speaking, Gaiman does Gothic old-school" $(2008,78)$, our agreement would purely be in terms of his literal evocation of Gothic tropes and figures. In truth, the Gothic is a means to an end for Gaiman, I would argue. Grim settings and grisly occurrences are certainly present in his Gothic texts, but Gaiman's redeployment of Gothic tropes occurs on the narrative and visual levels, in effect controlling and containing the Gothic threats that plague his protagonists. In spite of this novel being set in a graveyard inhabited by ghost and ghouls, the ghosts are anything but threatening, thus turning a world of horrors and hauntings into a welcoming home. In the graphic novel, the ghosts also display a transparency and depth of focus that distinguish them from the "real" people who visit the graveyard, and the artists' attention to the ghosts' visual detail is significantly greater at first than to the "real" characters (Bod and Scarlett Amber Perkins), who resemble stock characters from comics. The arguments that the ghosts have with each other over whether they will shelter the infant Bod also minimize their threat for the reader, as their petty arguments make them objects of humour rather than horror. In inventing backstories for these ghosts, in making them more "human," if you will, Gaiman destroys any fear a young reader might feel about these spectres. In this revision of the Gothic topos, then, Gaiman's graveyard and its ghostly inhabitants paradoxically become more "real" for his protagonist and young reader; and, in turn, the danger of the reader's "real" world is pushed to the side during the reading of the story.

Gaiman's transformation of the Gothic also occurs in his characterization. Gaiman, for example, complicates the conventional Gothic villain in The Graveyard Book and even redeploys him as a helper figure. As the editors of The Gothic in Children's Literature remind us, the villain in Gothic literature is often an "ambiguously attractive character" (Jackson, Coats, and McGillis 2008, 7), but the moral lines are very clearly drawn, such that there is never any suggestion that a villain's evil might simply be misunderstood. In his novel, Gaiman repurposes what should have conventionally been the villain - the vampire, Silas as Bod's protector and eventual godfather. Dave McKean's two illustrations of Silas mimic Gaiman's modification of the Gothic villain by depicting him as a rather ordinary-looking father-figure. More to the point, McKean destabilizes the villain figure visually even more, in that both images of Silas differ significantly from each other (see fig. 3). Whereas the first image depicts Silas as a balding, hunched-over older man dressed in an oversized coat, the second depicts Silas as a younger, hippyish man who wears glasses (see fig. 4). Neither of these images speaks to Silas's membership of the Undead. 


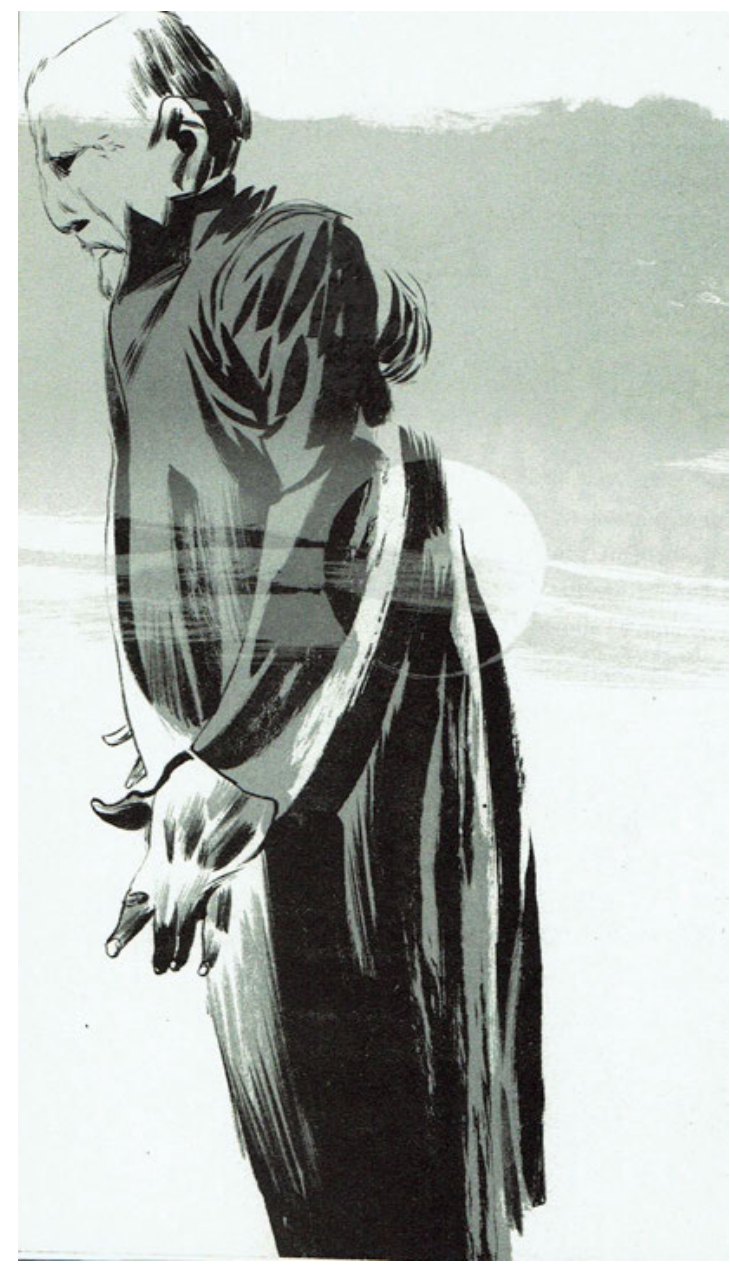

Fig. 3: Neil Gaiman, The Graveyard Book, illustrated by Dave McKean (New York: Harper, 2008), 36. () Neil Gaiman.

Chris Riddell, in contrast, plays up Silas's vampiric state. The image of Silas that graces the cover of Riddell's edition of the novel features what appears to be a Victorian gentleman with trousers, waistcoat, and necktie. Riddell's visuals suggest that Silas is not threatening, and in fact, is more of a caregiver to the young protagonist than a threat; his physical position in relation to Bod is quite protective. In the two-volume graphic novel adaptation, the graphic artists have more fun depicting Silas as a vampire, with all of the traditional expectations that come with this Gothic figure: red eyes, clawlike hands, papery white skin, and long, flowing black cape. Galen Showman's representation of Silas, for example, is reminiscent of both Bram Stoker's Dracula and Batman, reflecting in general the comics work 


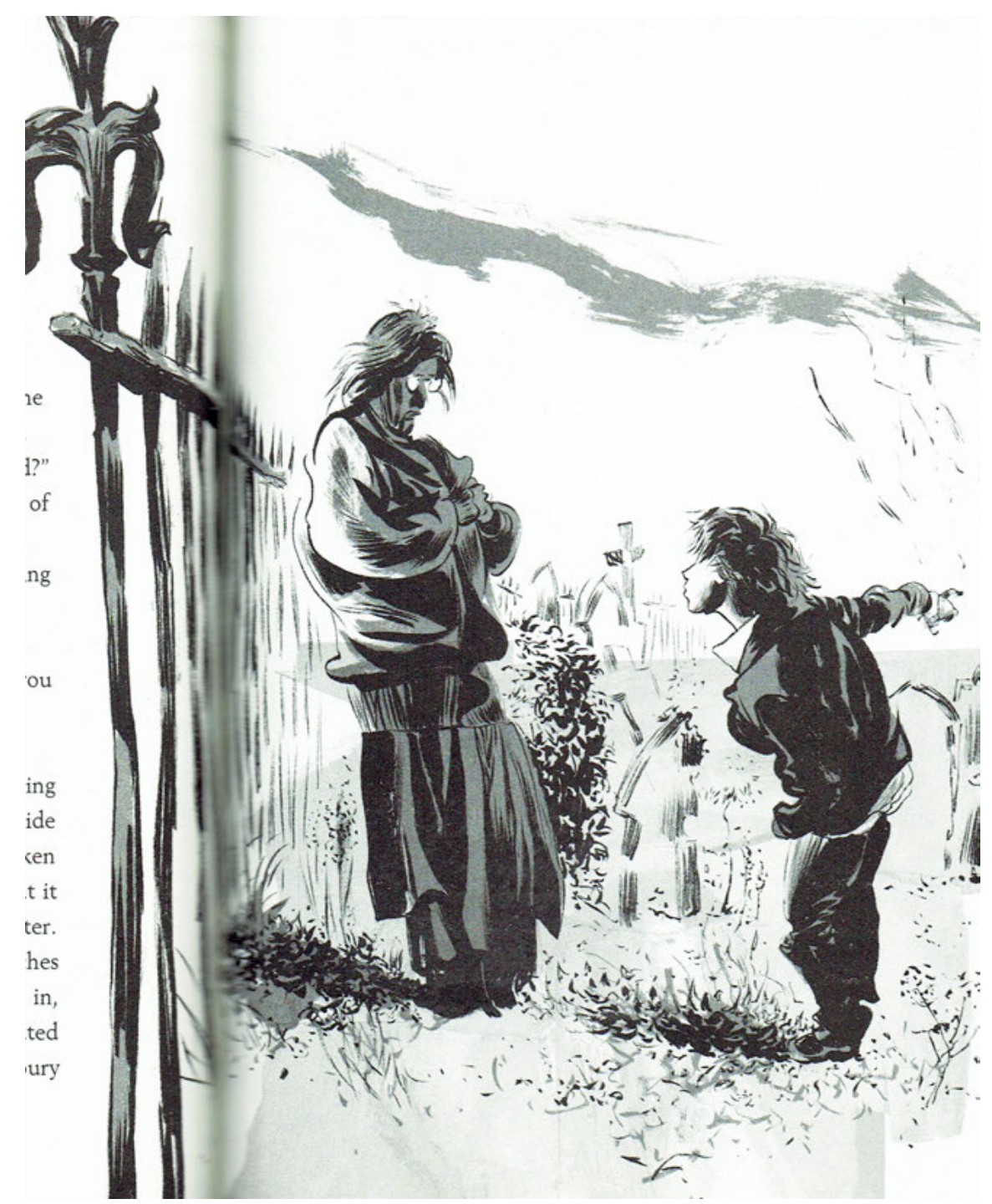

Fig. 4: Neil Gaiman, The Graveyard Book, illustrated by Dave McKean (New York: Harper, 2008), 101. () Neil Gaiman. 
that all of these graphic artists have done for Marvel, DC Comics, America's Best Comics, Dark Horse, and Vertigo Comics. ${ }^{2}$ In the graphic novel, Silas presents the perfect opportunity to consider Barthes's "stereophony of echoes, citations, references” $(1977,160)$ that distinguishes the practice of adaptation. Each of the illustrators interprets Silas distinctly by playing with the familiar characteristics of the vampire. Although, visually, Showman's Silas appears to be a villain typical of Gothic literature, in actuality he inspires confidence and provides a sense of belonging and protection, entirely in keeping with Gaiman's source text.

As Gothic tales rely on an "ambiguously attractive" villain (Jackson, Coats, and McGillis 2008, 7), Gaiman introduces a villain in his novel - the would-be murderer Jack, who is part of a fraternity of men, the "Jacks of All Trades," who wish to kill Bod because, millennia before, they had been warned of the coming of a child who would bring an end to their order and all they stood for. This Jack, however, is just a token nod to the Gothic villain in the sense that Bod's murderer is structurally needed to advance the plot. Jack is in no way flamboyant or powerful; in fact, he spends fifteen years trying to track down Bod to finish the job, as it were, and even then, he fails. Gaiman's description of the initial meeting between Jack and Silas in the graveyard deliberately highlights this contrast between villain and protector:

The man Jack was tall. This man was taller. The man Jack wore dark clothes. This man's clothes were darker. People who noticed the man Jack when he went about his business and he did not like to be noticed - were troubled, or made uncomfortable, or found themselves unaccountably scared. The man Jack looked up at the stranger, and it was the man Jack who was troubled. (Gaiman 2008b, 13)

Fascinatingly, the descriptions that Gaiman offers of Jack and Silas are minimal and communicate more through understatement, leaving in the process much room for his future adapters to invent to suit their own particular context.

2 Kevin Nowlan's first published work for Marvel Comics was Doctor Strange \#57 (February 1983); his character Jack B. Quick, created with Alan Moore, appeared several times in Tomorrow Stories under the America's Best Comics imprint. At DC Comics, P. Craig Russell inked Batman stories in Batman Family and Detective Comics. Russell's first Elric story was published by Marvel Comics in 1982 as Marvel Graphic Novel \#2. Dark Horse Comics eventually published Russell's adaptation of Wagner's operatic cycle, The Ring of the Nibelung, in two volumes. Galen Showman collaborated with P. Craig Russell on The Clowns for Dark Horse Comics and JLA: Age of Wonder for DC. In 1994, Tony Harris rose to prominence as a comics artist with the publication of DC Comics' Starman. Jill Thompson is well known for her work on Neil Gaiman's The Sandman characters and her own Scary Godmother series; she has also worked on The Invisibles, Swamp Thing, and Wonder Woman. David Lafuente is best-known for his work on Ultimate Comics: Spider-Man. 
The visual adaptations of The Graveyard Book capture the man Jack's narrative ambivalence, each in its own particular way. Riddell chooses to begin his edition of Gaiman's novel with an illustration of the man Jack, which in turn becomes typical of the Gothic aesthetic that Riddell employs subsequently. Jack's hunched-over body, the long knife he wields, and his crouching shadow emphasize the threat that this Gothic monster presents to the inhabitants of the suburban home, whom he murders seconds later. Jack's terrible threat thus introduces the narrative in this illustration. In the course of his visuals, however, Riddell mixes humour and horror, so typical of the Gothic. In one of the later illustrations for the novel, Riddell provides a portrait of the Jacks, who appear to be thugs rather than members of an exclusive, secret society. Wrestler types with bulbous noses that look as though they have been broken a few too many times hardly convey the threat that one might expect in a Gothic story, but this is totally in keeping with Gaiman's own adjustment of the Gothic. Likewise, in the graphic novel adaptation, Kevin Nowlan's visual interpretation of Jack depicts the villain as singularly unthreatening, relatively "normal” looking, if working class. Jack's cap, overcoat, and gloves do not evoke the same kind of thrills and chills that Silas's aristocratic cape would. More generally, these particular visual representations of Gaiman's villain comment on the adaptability of the Gothic in general, in the sense that each is as familiar as The Graveyard Book despite its novelty.

\section{Gaiman's visualization of childhood}

At the centre of Gaiman's Gothic story is its young protagonist, whose very life is threatened by this secret sect, the "Jacks of All Trades." In many ways, Bod is typical of the Gothic mode in that, initially anyway, he is established as a victim of wrongdoing, as the mysterious man Jack murders his entire family one night and devotes the next fifteen or so years trying to find him to finish the job. The visual adaptations of The Graveyard Book at first highlight Bod's childlike vulnerability in relation to the Gothic threat that life outside the graveyard promises. Sheltered in a crypt, sleeping in a coffin, clothed in a winding sheet, and given the Freedom of the Graveyard, Bod occupies the liminal position of living, while spending many of his formative years in company with the dead. He learns to see in the darkness, to slip and to fade. Bod learns his alphabet from headstones and from books that his godfather Silas smuggles into the graveyard, including primers and Dr Seuss's The Cat in the Hat. In keeping with Gaiman's development of Bod as an innocent child, Chris Riddell depicts Bod as such a spectacle of innocence, wrapped in his winding sheet, being carried along by the oddly repulsive creatures - the Duke 
of Westminster, the Honourable Archibald Fitzhugh, and the Bishop of Bath and Wells - through the Ghoul-gate and down into Ghulheim. In the graphic novel adaptation, Kevin Nowlan's visualization of the toddler Bod is in turn reminiscent of Richard F. Outcault's Yellow Kid and Winsor McCay's Little Nemo in early American comic history: Bod's childlike innocence is further emphasized through the visual synecdoches of the teddy bear and the crib (see fig. 5).

Nowlan highlights Bod's vulnerability visually when he depicts Bod in front of the graveyard's imposing and locked wrought-iron gates, looking for protection after the brutal murder of his entire family. Fred Botting suggests that this representation of childhood is quite typical of the literary Gothic: "Parentless children are left to roam the wild, gloomy landscapes without protection or property and often without the secure sense of themselves that comes with proper name and position" (2008, 33-34). In losing his entire family suddenly and violently, Bod embodies two of the primary fears of children: fear of abandonment and fear of being overpowered (Howarth 2014, 11). Bod's simple, childlike, and cartoonish features thus invite the reader's identification, as the graphic artists encourage the reader's empathy for this apparent victim of horrors. As Scott McCloud affirms, "the more cartoony a face is, for instance, the more people it could be said to describe" (1994, 31). Each of the visual adaptations of Gaiman's novel emphasizes the graveyard as a safehaven, a refuge, a home, even, that quite literally offers this parentless child protection from the threats of the outside world, for a finite period of time at least. Like Bod, a contemporary young reader can find comfort in this homely (and heimlich) Gothic world.

More importantly, Gaiman empowers the child, emphasizing the personal agency Bod develops over the course of fifteen years spent living in a cemetery. Narrative and visual humour is one of the principal methods with which Bod demonstrates this newfound agency. Ludic moments provide liberating opportunities for Gaiman's child-protagonist. The critic Julie Cross reminds us that hysterical laughter serves as a kind of comic relief from the fearful aspects of the Gothic narrative, allowing texts to deal with children's deepest, darkest, unspoken fears in a humorous way $(2008,59)$. Thus, when Bod and Scarlett descend into the hill to visit the oldest grave and find the Indigo Man, a quite awesome mystical creature who tries to scare them, the youngsters yawn at his scare tactics, dissolving any fear and achieving mastery over the Gothic. While Scarlett describes the bogey as "the tattooey man," Bod inspects and finally dismisses him as being only "imaginary” (Gaiman 2008a, 54). P. Craig Russell highlights the bogey's loss of power visually by depicting the Indigo Man lying down, curling up, and fading away. Fascinatingly, Russell's Indigo Man echoes Chris Riddell's earlier visualization of this character, with its spinning eyeballs, corpse-like body, crazy hair, and sharp talons. Both visualizations of the Indigo Man clearly establish the character 

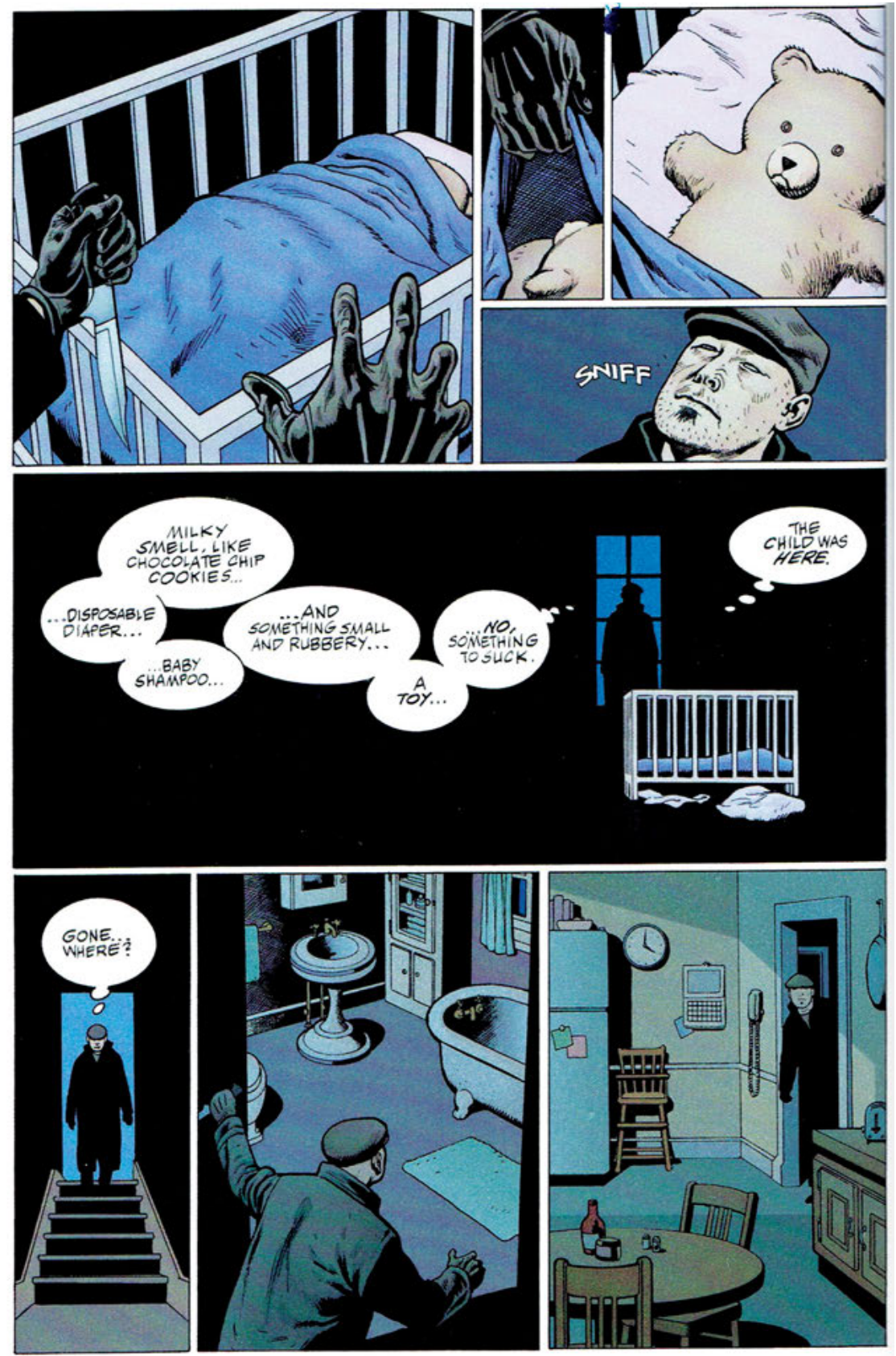

Fig. 5: Neil Gaiman, The Graveyard Book, The Graphic Novel Adaptation, P. Craig Russell, volume 1 (New York: Harper, 2014), 6. (c) Neil Gaiman. 
as an exotic monster, but one that presents no threat whatsoever. In fact, this Gothic monster becomes a spectacle of ridicule, mixing humour and horror in a way that is typical of the children's Gothic. And it is Bod's mastery of this fear that prepares him to move past his desire to avenge the murders of his biological family and to go out into the world and seize his potential.

Botting's characterization of the Gothic as a "hybrid form" $(1996,14)$ is especially well suited to the dynamic and dialogic relationship that exists between and among the illustrated editions of The Graveyard Book, which are, like many adaptations, "haunted at all times by their adapted texts" (Hutcheon 2013, 6). Each visual adaptation of The Graveyard Book offers a plural "stereophony of echoes, citations, references," as Roland Barthes $(1977,160)$ once characterized adaptation, for each illustrated version openly announces its relationship to another work or works. "Adaptation is an act of appropriating or salvaging," Linda Hutcheon goes on to remind us, "and this is always a double process of interpreting and then creating something new" $(2013,20)$. Once a genre that inspired fear among Enlightenment theorists of the "gross stimulants" that Gothic stories offered young readers, the prevalence of the children's Gothic in the eighteenth and nineteenth centuries, and its omnipresence in the twentieth and twenty-first, proves that fear and the pretence of fear have always held great interest for youthful readers. As such, "children's and young adult texts have become veritable playgrounds for revising and expanding the Gothic chronotope" (Jackson, Coats, and McGillis 2008, 6). Neil Gaiman makes much of this fascination with ghosts and ghouls in The Graveyard Book. He redeploys them, however, to foreground the process of becoming that his young protagonist experiences, the process by which Bod sheds himself of his past in his acceptance of his new agency as a young man. In turn, Gaiman's rethinking of the Gothic world and mode is exciting for the illustrators and graphic artists of his texts, who adapt his Gothic elements to their own different contexts. Mirroring in visual fashion Gaiman's revisionist approach to the Gothic in The Graveyard Book, these artists help to transform the Gothic world into a world of possibility for reader and viewer, in which a youthful reader is encouraged to participate in the process of making meaning. 


\section{Works cited}

Barthes, Roland. Image - Music - Text. Trans. Stephen Heath. New York: Hill \& Wang, 1977. Botting, Fred. Gothic. London: Routledge, 1996.

Botting, Fred. Limits of Horror: Technology, Bodies, Gothic. Manchester: Manchester University Press, 2008.

Buckley, Chloe Germaine. “Psychoanalysis, 'Gothic' Children's Literature, and the Canonization of Coraline." Children's Literature Association Quarterly 40.1 (2015): 58-79.

Coats, Karen. "Between Horror, Humour, and Hope: Neil Gaiman and the Psychic Work of the Gothic.” The Gothic in Children's Literature: Haunting the Borders. Ed. Anna Jackson, Coats, and Roderick McGillis. New York: Routledge, 2008. 77-92.

Cross, Julie. "Frightening and Funny: Humour in Children's Gothic Fiction." The Gothic in Children's Literature: Haunting the Borders. Ed. Anna Jackson, Karen Coats, and Roderick McGillis. New York: Routledge, 2008. 57-76.

Gaiman, Neil. The Graveyard Book. Illus. Dave McKean. New York: Harper, 2008a.

Gaiman, Neil. The Graveyard Book. Illus. Chris Riddell. New York: Harper, 2008b.

Gaiman, Neil. The Graveyard Book. Illus. Kevin Nowlan et al. 2 vols. New York: Harper, 2014.

Gamer, Michael. Romanticism and the Gothic: Genre, Reception, and Canon Formation. New York: Cambridge University Press, 2000.

Halsall, Alison. “Nobody's Home: Neil Gaiman's The Graveyard Book and Its Visual Adaptations." INKS: The Journal of the Comics Studies Society 1.3 (2017): 334-353. Howarth, Michael. Under the Bed, Creeping: Psychoanalyzing the Gothic in Children's Literature. Jefferson: McFarland, 2014.

Hutcheon, Linda. A Theory of Adaptation. London: Routledge, 2013.

Jackson, Anna, Karen Coats, and Roderick McGillis. "Introduction.” The Gothic in Children's Literature: Haunting the Borders. Ed. Jackson, Coats, and McGillis. New York: Routledge, 2008. 1-14.

McCloud, Scott. Understanding Comics: The Invisible Art. New York: HarperCollins, 1994. McGillis, Roderick. "The Night Side of Nature: Gothic Spaces, Fearful Times.” The Gothic in Children's Literature: Haunting the Borders. Ed. Anna Jackson, Karen Coats, and McGillis. New York: Routledge, 2008. 227-241.

Nikolajeva, Maria, and Carole Scott. How Picturebooks Work. New York: Garland, 2001.

Round, Julia. Gothic in Comics and Graphic Novels: A Critical Approach. Jefferson: McFarland, 2014.

Townshend, Dale. “The Haunted Nursery: 1764-1830.” The Gothic in Children's Literature: Haunting the Borders. Ed. Anna Jackson, Karen Coats, and Roderick McGillis. New York: Routledge, 2008. 15-38.

Wright, Angela. Gothic Fiction: A Reader's Guide to Essential Criticism. Houndmills and Basingstoke: Palgrave Macmillan, 2007. 
Dr Halsall is an assistant professor in the Department of Humanities at York University, Toronto, Canada. She holds a $\mathrm{PhD}$ in English Literature, with specialties in the Victorian period and modernisms, with an emphasis on visual cultures. Her current research examines "crisis comics" for and about children and youth, and the particular interface of graphic literature and human rights discourse in recent literature for young people. She published an edition of H.D.'s White Rose and the Red with the University Press of Florida. INKS: The Journal of the Comics Studies Society recently published her article about visual adaptations of The Graveyard Book. "'What is the use of a book ... without pictures or conversations?': Incorporating the Graphic Novel into the University Curriculum” (2017) explores the graphic novel as a complex, heterogeneous form, thanks to the collaboration it requires between an artist or artists and a writer, the interanimations it showcases between word and image, and the intertextual possibilities it opens up with other visual and literary texts. She has also published articles about the Pre-Raphaelites, Penny Dreadful, South Park, Harry Potter, and neo-Victorianism in contemporary graphic novels. 
